\title{
Residual Effects of Lime- and Clay-Amended Biosolids Applied to Coarse-Textured Pasture Soil
}

\author{
Sanjutha Shanmugam and Lynette K. Abbott \\ Soil Biology and Molecular Ecology Group, School of Earth and Environment and UWA Institute of Agriculture, Faculty of Science, \\ The University of Western Australia, 35 Stirling Highway, M087, Crawley, WA 6009, Australia \\ Correspondence should be addressed to Sanjutha Shanmugam; sanjutha.shanmugam@gmail.com
}

Received 18 September 2014; Accepted 23 November 2014

Academic Editor: Rodrigo Studart Corrêa

Copyright (c) 2015 S. Shanmugam and L. K. Abbott. This is an open access article distributed under the Creative Commons Attribution License, which permits unrestricted use, distribution, and reproduction in any medium, provided the original work is properly cited.

\begin{abstract}
This study investigated whether there was residual effect of application of lime- and clay-amended biosolids $\left(\right.$ LaBC $\left.^{\circledR}\right)$ on ryegrass growth and soil microbial biomass in a coarse-textured, acid pasture soil. Reapplied LaBC ${ }^{\circledR}$ increased fertiliser-use efficiency and plant growth in this glasshouse experiment. Soil management history was established with a single application of $\mathrm{LaBC}^{\circledR}\left(50 \mathrm{tha}^{-1}\right.$ wet weight equivalent) with or without inorganic fertiliser (NPK) prior to growing annual ryegrass for 5 cycles. In cycle 6 there was no residual nutrient effect of the original application of $\mathrm{LaBC}^{\circledR}$ but there was a residual liming effect of the previously applied $\mathrm{LaBC}^{\circledR}$. A nutrient effect of reapplied $\mathrm{LaBC}^{\circledR}$ in plant growth cycle 6, had little residual benefit in cycle 7 . The residual concentration of inorganic $\mathrm{N}$ remaining in this coarse-textured acid soil after a single application of $\mathrm{LaBC}^{\circledR}$ was negligible and did not appear to be a risk to the environment when applied at $50 \mathrm{tha}^{-1}$ wet weight equivalent.
\end{abstract}

\section{Introduction}

Soils on the Swan Coastal Plain in Western Australia (WA) are generally coarse-textured and nutrient deficient and need remedial measures to address soil conditions such as acidity [1]. In addition, these soils are characterised by water repellence that leads to poor water-infiltration and poor nutrient and water retention capabilities in soil that eventually can cause problems for the quality of nearby waterways [2]. Appropriate soil management and nutrient application practices are needed to provide better conditions for plant growth and to reduce the potential for nutrient leaching into waterways on the Swan Coastal Plain $[3,4]$. It has been suggested that lime-amended biosolids further blended with clay (called $\mathrm{LaBC}^{\circledR}$ ) could be incorporated as a soil amendment to remediate these sandy soils [5]. However, the nutrient release pattern for plant available $\mathrm{N}$ from $\mathrm{LaBC}^{\circledR}$ and considerations for a potential long-term nutrient release need to be monitored to ensure safe recycling of nutrients in this acid sandy soil [6].

Amending soil with biosolids can increase plant growth in degraded pastures associated with improvements in soil fertility [7-9]. Pasture productivity can be increased with application of both organic and inorganic sources of nutrients in such soils [10-13]. Liming, alone or in the form of alkaline stabilised sewage sludge (biosolid), has been used to alleviate soil acidity [14-16]. Various forms of biosolids are available for use in agriculture, including lime-stabilised biosolids [17, 18 ] and a modified clay-amended biosolid product $\left(\mathrm{LaBC}^{\circledR}\right)$ which was created for use on acid sandy soils of the Swan Coastal Plain in WA $[5,19] . \operatorname{LaBC}^{\circledR}$ is similar to a biosolid product that was developed by mixing biosolids with riversediments for application to native grasses in Illinois, USA [20].

Soil management practices that include amending soils with organic or inorganic fertilisers can release residual nutrients ( $\mathrm{N}$ and $\mathrm{P}$ ) for some time after their application $[21,22]$. Several studies have demonstrated residual effects of applied amendments such as biosolids [23-26], inorganic fertilisers [27, 28], and lime [29-31] that increased soil macronutrients and microbial dynamics in a range of degraded and agricultural lands. A recent study in a sandyloam soil demonstrated a differential effect on $\mathrm{N}$ availability for a repeated application of fertiliser and/or organic manures 
TABLE 1: Pretreatment details for the establishment of a pasture soil history during 5 cycles of growth of annual ryegrass in a coarsetextured acid soil under glasshouse conditions.

\begin{tabular}{|c|c|}
\hline Initial soil treatments & $\begin{array}{c}\text { Fertiliser applied in } 5 \text { previous cycles } \\
\text { of annual ryegrass by the Water } \\
\text { Corporation of Western Australia }\end{array}$ \\
\hline Control & Not applied \\
\hline${ }^{\mathrm{a}} \mathrm{LaBC}^{\circledR}$ & Not applied \\
\hline${ }^{\mathrm{b}}$ Fertiliser & Applied \\
\hline $\mathrm{LaBC}^{\circledR}+$ fertiliser & Applied \\
\hline $\begin{array}{l}{ }^{\mathrm{a}} \mathrm{LaBC}^{\circledR}=50 \mathrm{tha}^{-1} \text { of we } \\
\text { cycle. } \\
{ }^{\mathrm{b}} \text { Fertiliser }=\text { macronutrien } \\
\text { each cycle. }\end{array}$ & $\begin{array}{l}\text { ht equivalent applied once only in the first } \\
\text { liser applied according to district practice at }\end{array}$ \\
\hline
\end{tabular}

in a 17-year experimental site [22]. Long-term $\mathrm{N}$ application stimulated gross nitrification more than 5.3 times and soil organic matter was 2.7 times greater in fertiliser applied treatments. A 2-year study concluded that sewage sludge used as an organic amendment was not a complete substitute for mineral fertilisers as inorganic nutrient inputs resulted in greater ryegrass growth on a land-fill site restored with London clay [32]. The $\mathrm{N}$ release pattern for the supply of plant available nutrients from biosolids or fertilisers needs to be independently assessed according to the rate applied and soil conditions, because a generalised approach for estimating nutrient supply has several limitations when budgeting nutrient release [33].

In our previous study, clay addition to lime-amended biosolids $\left(\mathrm{LaBC}^{\circledR}\right)$ increased microbial biomass in an acid sandy soil, which was associated with an increase in soil $\mathrm{pH}$ when the amendments were incubated for 30 weeks [19]. It was also found that $\mathrm{N}$ was released over a longer period when clay was added to the biosolid with lime (as $\mathrm{LaBC}^{\circledR}$ ) rather than when either clay or lime was added independently [19]. In addition, a long-term effect of $\mathrm{LaBC}^{\circledR}$ and its potential for supplying plant nutrients has been investigated using ryegrass at both field and glasshouse scales [6]. However, the residual effect of $\mathrm{LaBC}^{\circledR}$ on soil fertility, especially in relation to microbial activities, is not known. Therefore, in order to study the residual effects of $\mathrm{LaBC}^{\circledR}$ on soil fertility, LaBC $^{\circledR}$ was initially applied once as a basal amendment with initial and repeated applications of inorganic fertiliser containing $\mathrm{N}, \mathrm{P}, \mathrm{K}, \mathrm{Ca}$, and $\mathrm{Mg}$ before sowing 5 sequential cycles of ryegrass. This established a fertiliser history in the glasshouse experiment (Table 1). Subsequently, the residual concentration of $\mathrm{N}$ remaining in the soil after these 5 growth cycles was assessed after a single reapplication of $\mathrm{LaBC}^{\circledR}$ in a sixth growth cycle of ryegrass (Figure 1). The residual effectiveness of this reapplied $\mathrm{LaBC}^{\circledR}$ was also determined in a seventh growth cycle. Ryegrass biomass, soil inorganic $\mathrm{N}, \mathrm{pH}$, and soil microbial biomass $\mathrm{N}$ were assessed after the sixth and seventh cycle of ryegrass.

The aim was to determine whether there was a residual effect of $\mathrm{LaBC}^{\circledR}$ application or an effect of reapplication of $\mathrm{LaBC}^{\circledR}$ to soil that is with a history of $\mathrm{LaBC}^{\circledR}$ application. This was assessed with and without the application
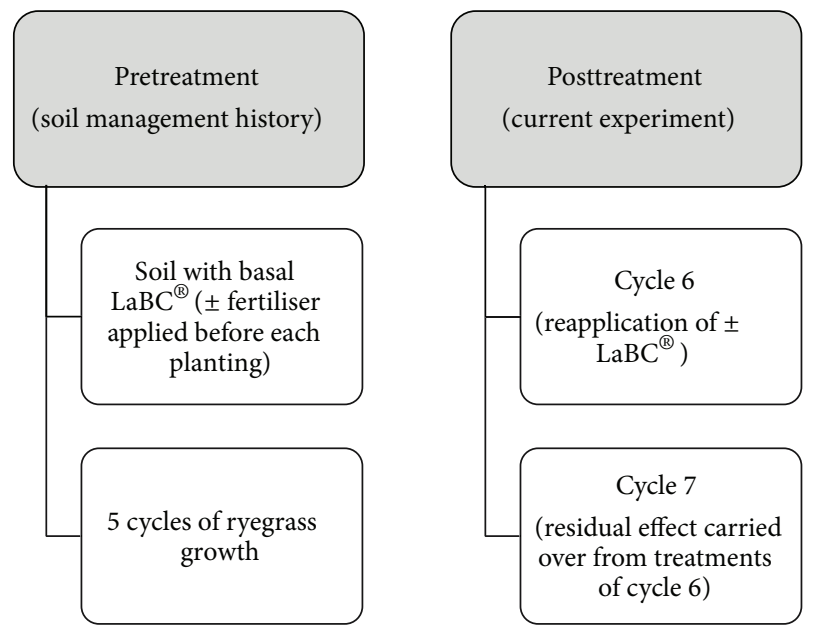

FIGURE 1: Steps involved in determining the residual effect of $\mathrm{LaBC}^{\circledR}$ in either the presence or absence of added fertilizer. Dry $\mathrm{LaBC}^{\circledR}=$ $50 \mathrm{t} \mathrm{ha}^{-1}$ of wet weight equivalent; fertiliser $=$ macronutrient fertilisers $(\mathrm{N}, \mathrm{P}, \mathrm{K}, \mathrm{Ca}$, and $\mathrm{Mg})$ applied according to district practice.

of basal inorganic fertiliser to determine whether there is potential environmental risk from application of $\mathrm{LaBC}^{\circledR}$. It was hypothesised that (i) reapplication of $\mathrm{LaBC}^{\circledR}$ would have an immediate effect of increasing soil $\mathrm{pH}$ regardless of prior history of $\mathrm{LaBC}^{\circledR}$ and fertiliser application and (ii) application of $\mathrm{LaBC}^{\circledR}$ to soil with a fertiliser history would release more $\mathrm{N}$ and increase ryegrass growth to a greater extent than an application of $\mathrm{LaBC}^{\circledR}$ to soil without a fertiliser history.

\section{Materials and Methods}

\subsection{Experimental Design}

2.1.1. Pretreatment of Soil with $L a B C^{\circledR}$ and Fertilizer for Establishing Soil Management History. Soil used for this experiment was taken from pots that had been pretreated under controlled glasshouse conditions in the following way by the Water Corporation of Western Australia (WA). Prior to establishing the fertiliser history, a coarse-textured acidic sandy soil had been collected from a depth of $0-10 \mathrm{~cm}$ after removing coarse surface litter. The field was adjacent to a site with natural woodland vegetation at Bullsbrook $\left(31^{\circ} 40^{\prime} 0^{\prime \prime}\right.$ South, $116^{\circ} 0^{\prime} 0^{\prime \prime}$ East), WA, and represented the Swan Coastal Plain-Bassendean sands of the Ellen Brook catchment (pale deep, bleached-Orthic Tenosol [34]). The soil had been airdried and passed through a $4 \mathrm{~mm}$ sieve. It was dominated by sand $(98 \% ; 20 \mu \mathrm{m}-2 \mathrm{~mm})$ with a small silt fraction $(2 \%$; $<20 \mu \mathrm{m})$. Soil chemical properties were $\mathrm{pH}\left(\mathrm{CaCl}_{2}\right) 5.1$, total carbon $1.3 \%$, total nitrogen $0.1 \%$, total oxidisable carbon $0.15 \mathrm{mg} \mathrm{g}^{-1}$, and inorganic nitrogen $0.8 \mu \mathrm{g} \mathrm{g}^{-1}$.

Free draining pots $(175 \mathrm{~mm}$ in diameter, $2.8 \mathrm{~L})$ had been filled with $5 \mathrm{~kg}$ of soil, packed to a bulk density of $1.6 \mathrm{~g} \mathrm{~cm}^{-3}$ (Water Corporation of WA). The pots had been placed inside a bucket to simulate leaching after irrigation under controlled glasshouse conditions. Dry $\mathrm{LaBC}^{\circledR}\left(50 \mathrm{t} \mathrm{ha}^{-1}\right.$ wet weight equivalent, 2 to $4 \mathrm{~mm}$ ) had been applied in cycle 1 , 
TABLE 2: Single basal and reapplication of $\mathrm{LaBC}^{\circledR}$ during 7 cycles of ryegrass grown in pots of coarse-textured, acid soil under glasshouse conditions to determine the residual effects of $\mathrm{LaBC}^{\circledR}$.

\begin{tabular}{|c|c|c|}
\hline Ryegrass cycles 1 to 5 & Ryegrass cycle 6 & Ryegrass cycle 7 \\
\hline $\begin{array}{l}\text { History of single basal } \\
\text { application of } \mathrm{LaBC}^{\circledR}+/- \\
\text { fertiliser }\end{array}$ & $\begin{array}{l}\mathrm{LaBC}^{\circledR} \text { reapplied to soil from half of each } \\
\text { pot after cycle } 5\left(+\mathrm{LaBC}^{\circledR}\right) \\
\text { Remaining soil was untreated }\left(-\mathrm{LaBC}^{\circledR}\right)\end{array}$ & $\begin{array}{l}\text { No LaBC }{ }^{\circledR} \text { added in this cycle } \\
\text { (to all prior treatments) }\end{array}$ \\
\hline Control & $+/-\mathrm{LaBC}^{\circledR}$ & $-\mathrm{LaBC}^{\circledR}$ \\
\hline${ }^{\mathrm{a}} \mathrm{LaBC}^{\circledR}$ & $+/-\mathrm{LaBC}^{\circledR}$ & $-\mathrm{LaBC}^{\circledR}$ \\
\hline${ }^{\mathrm{b}}$ Fertiliser & $+/-\mathrm{LaBC}^{\circledR}$ & $-\mathrm{LaBC}^{\circledR}$ \\
\hline $\mathrm{LaBC}^{\circledR}+$ fertiliser & $+/-\mathrm{LaBC}^{\circledR}$ & $-\mathrm{LaBC}^{\circledR}$ \\
\hline
\end{tabular}

${ }^{\mathrm{a}} \mathrm{LaBC}^{\circledR}=50 \mathrm{tha}^{-1}$ of wet weight equivalent applied in cycle 6.

${ }^{\mathrm{b}}$ Fertiliser $=$ macronutrient fertiliser applied according to district practice at each cycle.

and macronutrient fertiliser treatments (district practice) had been applied in each cycle according to the treatment schedule (Table 1). The amendments had been fully incorporated through the soil prior to planting ryegrass seeds. Macronutrient fertiliser had been applied on the soil surface prior to planting ryegrass where applicable in each of the 5 cycles (Table 1). The macronutrients had been applied at district farming practice rates equivalent to Flexi $\mathrm{N}\left(11.88 \mathrm{~kg} \mathrm{ha}^{-1}\right)$, triple superphosphate $\left(20.03 \mathrm{~kg} \mathrm{ha}^{-1}\right), \mathrm{K}_{2} \mathrm{SO}_{4}\left(54.51 \mathrm{~kg} \mathrm{ha}^{-1}\right)$, $\mathrm{CaCl}_{2}\left(30.67 \mathrm{~kg} \mathrm{ha}^{-1}\right)$, and $\mathrm{MgSO}_{4}\left(26.62 \mathrm{~kg} \mathrm{ha}^{-1}\right)$. Each treatment had been replicated 3 times and pots watered with deionised water had been maintained at $60 \%$ field capacity throughout this pretreatment experimental phase.

For the pretreatment conducted by the Water Corporation of WA, seeds of annual ryegrass (Lolium multiflorum, cultivar Winter Star) had been pregerminated in Petri dishes and 12 seedlings of uniform size transplanted into each pot as 1-week-old seedlings. Plants had been grown for six weeks after transplanting and the plant biomass was harvested at the end of each growth cycle. Following each harvest, pots had been returned to the glasshouse with a simulated fallow of approximately 2 weeks without irrigation. Following this 2 week period, all contents had been emptied from pots and passed through a sieve $(4 \mathrm{~mm})$ to remove coarse root debris. After each fallow period, the pots had been planted with new set of 1-week-old seedlings and macronutrient fertilisers were applied to the soil surface according to treatment schedule (Table 1). The same method had been repeated in total for five cycles of ryegrass growth and harvests. The entire process of establishing the soil history is summarised in the flow diagram (Figure 1).

2.1.2. Reapplication of $\mathrm{LaBC}^{\circledR}(+/-)$ to Soil for Cycles 6 and 7 of Ryegrass. Soil from each pot, which had been exposed to pretreatment cycles 1 to 5 , was divided and placed into 2 equal smaller pots $(115 \mathrm{~mm}$ in diameter, $1.5 \mathrm{~L})$ prior to reapplication of treatments (Figure 1). $\mathrm{LaBC}^{\circledR}$ was reapplied at the start of cycle 6 (Table 2).

For cycles 6 and 7 , pots were filled with $1.65 \mathrm{~kg}$ of soil collected from the pretreated soil and packed to a bulk density of $1.6 \mathrm{~g} \mathrm{~cm}^{-3}$. Dry $\mathrm{LaBC}^{\circledR}$ (2 to $4 \mathrm{~mm}$ fraction) was applied according to the treatment schedule (Table 2) and fully incorporated throughout the soil prior to planting. Pots were irrigated with deionised water and maintained at $60 \%$ field capacity level throughout the experiment. Plants were sown with ryegrass and harvested after 6 weeks in cycles 6 and 7 as described above for the 5 pretreatment cycles. Each treatment was replicated 3 times.

2.2. Characteristics of $\operatorname{LaBC} C^{\circledR}$. The $\mathrm{LaBC}^{\circledR}$ blend was air dried at $40^{\circ} \mathrm{C}$ and homogenised using a mechanical crusher. The amendment was then passed through a sieve that captured particles between 2 and $4 \mathrm{~mm}$ before application. Basic characteristics of the amendment were analysed using standard procedures [35]. The $\mathrm{pH}\left(\mathrm{CaCl}_{2}\right)$ was 8.2. Oxidisable $\mathrm{C}$ and carbonate contents were measured on $0.5 \mathrm{M} \mathrm{K}_{2} \mathrm{SO}_{4}$ extracts (sample-solution ratio of $1: 4$ ) using an autosampler (Shimadzu, ASI-5000 A) and TOC analyser (Shimadzu, TOC $5000 \mathrm{~A}$ ) based on wet combustion method [36]. $\mathrm{LaBC}^{\circledR}$ had $3 \%$ total $\mathrm{C}, 0.3 \%$ total $\mathrm{N}, 2.4 \mathrm{mg} \mathrm{g}^{-1}$ oxidisable C, $0.9 \mathrm{mg} \mathrm{g}^{-1}$ carbonate, $46 \mu \mathrm{g} \mathrm{g}^{-1}$ total inorganic $\mathrm{N}$, and traces of micronutrients such as $\mathrm{Zn}$ and $\mathrm{Cu}\left(\mathrm{mg} \mathrm{kg}^{-1}\right.$, dry weight basis).

2.3. Sampling and Analyses. Plants were harvested after 6 weeks in cycles 6 and 7. Shoots were cut just above the soil surface and their base was washed with deionised water to remove any adhering soil particles. Soil from each pot was then transferred to separate trays to collect root biomass; larger roots were gently removed by hand whereas the finer roots were removed by sieving through a $2 \mathrm{~mm}$ sieve. The soil was returned into the respective pots after removing the roots and root fragments. All plant samples were dried to a constant weight at $40^{\circ} \mathrm{C}$ for 7 days in a hot air oven and weighed to record dry weight biomass.

Soil subsamples (approximately $50 \mathrm{~g}$ ) were collected at the end of each harvest, after removing the finer root fragments and homogenising the soil from each pot. Soil $\mathrm{pH}(1: 5 \mathrm{v} / \mathrm{v}$ ratio of soil/ $/ 0.01 \mathrm{M} \mathrm{CaCl}_{2}$ suspension) was measured after shaking for 1 hour continuously in a mechanical end-overend shaker [35].

Soil inorganic $\mathrm{N}\left(\mathrm{NO}_{3}{ }^{-}-\mathrm{N}+\mathrm{NH}_{4}{ }^{+}-\mathrm{N}\right)$ was determined using fresh soil ( $10 \mathrm{~g}$ dry weight equivalent) extracts of $0.5 \mathrm{M}$ $\mathrm{K}_{2} \mathrm{SO}_{4}(40 \mathrm{~mL})$ after shaking in a mechanical end-overend shaker for 1 hour and microbial biomass $\mathrm{N}$ (MBN) 
TABLE 3: Shoot dry biomass $\left(\mathrm{g} \mathrm{pot}^{-1}\right)$ in ryegrass cycles 6 and 7 with reapplied $\operatorname{LaBC}^{\circledR}(+/-)$ as influenced by residual effects of soil amendments from previous management history.

\begin{tabular}{|c|c|c|c|c|}
\hline \multicolumn{5}{|c|}{ Shoot dry biomass $\left(\mathrm{g} \mathrm{pot}^{-1}\right)$} \\
\hline \multirow{3}{*}{$\begin{array}{l}\text { Soil management history } \\
\text { (cycles } 1 \text { to } 5 \text { ) }\end{array}$} & \multicolumn{2}{|c|}{ Ryegrass cycle 6} & \multicolumn{2}{|c|}{ Ryegrass cycle 7} \\
\hline & \multicolumn{4}{|c|}{ Current treatment $\left(+/-\mathrm{LaBC}^{\circledR}\right)$} \\
\hline & $-\mathrm{LaBC}^{\circledR}$ & $\begin{array}{l}+\mathrm{LaBC}^{\circledR} \\
\left(50 \mathrm{tha}^{-1}\right)\end{array}$ & $\begin{array}{c}\text { Treatment } \\
- \text { LaBC }^{\circledR} \text { from cycle } 6\end{array}$ & $\begin{array}{c}\text { Treatment } \\
+ \text { LaBC }^{\circledR} \text { from cycle } 6\end{array}$ \\
\hline Control & $0.03 \pm 0.03^{\mathrm{c}}$ & $0.33 \pm 0.03^{\mathrm{b}}$ & $0.11 \pm 0.02^{\mathrm{d}}$ & $0.38 \pm 0.04^{\mathrm{b}}$ \\
\hline${ }^{\mathrm{a}} \mathrm{LaBC}^{\circledR}$ & $0.10 \pm 0.00^{c}$ & $0.39 \pm 0.01^{\mathrm{b}}$ & $0.09 \pm 0.01^{\mathrm{d}}$ & $0.30 \pm 0.02^{\mathrm{c}}$ \\
\hline${ }^{\mathrm{b}}$ Fertiliser & $0.28 \pm 0.04^{\mathrm{b}}$ & $0.40 \pm 0.06^{\mathrm{b}}$ & $0.15 \pm 0.00^{\mathrm{d}}$ & $0.47 \pm 0.04^{\mathrm{a}}$ \\
\hline $\mathrm{LaBC}^{\circledR}+$ fertiliser & $0.33 \pm 0.03^{\mathrm{b}}$ & $0.60 \pm 0.06^{\mathrm{a}}$ & $0.11 \pm 0.02^{\mathrm{d}}$ & $0.40 \pm 0.04^{\mathrm{ab}}$ \\
\hline
\end{tabular}

${ }^{\mathrm{a}} \mathrm{LaBC}^{\circledR}=50 \mathrm{tha}^{-1}$ of wet weight equivalent.

${ }^{\mathrm{b}}$ Fertiliser $=$ macronutrient fertilisers $(\mathrm{N}, \mathrm{P}, \mathrm{K}, \mathrm{Ca}$, and $\mathrm{Mg})$ applied according to district practice.

Values are mean \pm SE $(n=3)$. The letters followed by mean \pm SE were based on LSD $(P<0.05)$.

The main and interaction effects of treatments with the same letters, within the same column and between columns within each cycle, respectively, were not significant $(P>0.05)$.

was determined using the same procedures in our previous experiments [19].

2.4. Statistical Analyses. Cycle 6 was set up in a complete randomised block design (4 pretreatment histories $\times 2$ LaBC $^{\circledR}$ posttreatments) with three replicates. Cycle 7 was the same as cycle 6. Statistical analyses were performed using Genstat version 12. Two-way analysis of variance (ANOVA) was used to compare the residual effect of the pretreatment soil management history on posttreatment of $\mathrm{LaBC}^{\circledR}$ and the least significant difference (LSD) was determined at $P \leq 0.05$.

\section{Results}

3.1. Shoot Dry Biomass $\left(g \mathrm{pot}^{-1}\right)$. Shoot biomass was significantly influenced $(P<0.05)$ only by fertiliser from the basal history but not by the previously applied $\mathrm{LaBC}^{\circledR}$, after 5 cycles of ryegrass planting (Table 3 ). When $\mathrm{LaBC}^{\circledR}$ was reapplied at $50 \mathrm{t} \mathrm{ha}^{-1}$ in cycle 6 , shoot biomass was increased (by $>100 \%$ ) compared to non-reapplied $\mathrm{LaBC}^{\circledR}$. A residual effect of reapplied $\mathrm{LaBC}^{\circledR}$ from cycle 6 was carried over to cycle 7.

3.2. Root Dry Biomass $\left(g\right.$ pot $\left.^{-1}\right)$. Root biomass was significantly influenced $(P<0.05)$ only by fertiliser from the basal history but not by the previously applied $\mathrm{LaBC}^{\circledR}$, after 5 cycles of ryegrass planting (Table 4 ). It was increased 3 -fold by the fertiliser from the prior history. When $\mathrm{LaBC}^{\circledR}$ was reapplied at $50 \mathrm{t} \mathrm{ha}^{-1}$ in cycle 6 , it did not have a significant effect regardless of the soil history. However, a residual effect of reapplied $\mathrm{LaBC}^{\circledR}$ from cycle 6 was carried over to cycle 7 .

3.3. Root: Shoot. Root: shoot was significantly increased $(P<0.05)$ by pretreatment of soil with both $\mathrm{LaBC}^{\circledR}$ and fertiliser and in combination when assessed in cycle 6 (Table 5). A residual effect of fertiliser but not $\mathrm{LaBC}^{\circledR}$ lasted through to cycle 7 . When $\mathrm{LaBC}^{\circledR}$ was reapplied at $50 \mathrm{tha}^{-1}$ in cycle 6 , it did not have a significant $(P>0.05)$ effect on root : shoot regardless of the soil history and the same pattern was also observed at cycle 7 (Table 5). Overall, the residual effect of fertiliser history significantly $(P<0.05)$ influenced the root: shoot but only in the absence of reapplied $\mathrm{LaBC}^{\circledR}$.

3.4. Shoot N Concentration (\%). Shoot N concentration was not influenced $(P>0.05)$ by $\mathrm{LaBC}^{\circledR}$ and/or fertiliser applied to the pretreated soil when assessed in cycle 6 (Table 6 ). When $\mathrm{LaBC}^{\circledR}$ was reapplied at $50 \mathrm{tha}^{-1}$ in cycle 6 , it did not have a significant $(P>0.05)$ effect regardless of the soil history and no residual effect of reapplied $\mathrm{LaBC}^{\circledR}$ was carried over to cycle 7 .

3.5. Soil $p H$. Soil $\mathrm{pH}\left(\mathrm{CaCl}_{2}\right)$ was significantly influenced $(P<0.05)$ by $\mathrm{LaBC}^{\circledR}$ applied to the pretreated soil when assessed in cycle 6 (Table 7 ). When LaBC $^{\circledR}$ was reapplied at $50 \mathrm{tha}^{-1}$ in cycle 6 , there was a further significant $(P<$ 0.05 ) increase (by 1-2 units) in soil $\mathrm{pH}$ regardless of the soil history. The residual effect of reapplied $\mathrm{LaBC}^{\circledR}$ from cycle 6 was carried over to cycle 7 and the $\mathrm{pH}$ increased by 0.5 units.

3.6. Soil Total Inorganic N. Soil total inorganic N was significantly $(P<0.05)$ increased by fertiliser only application with or without reapplied $\mathrm{LaBC}^{\circledR}$ in cycle 6 but not when LaBC $^{\circledR}$ was reapplied without fertiliser (Table 8 ). There was no residual $\mathrm{N}$ effect of reapplied $\mathrm{LaBC}^{\circledR}$ carried from cycle 6 on to cycle 7 .

3.7. Soil Microbial Biomass N. Soil microbial biomass $N$ was not significantly influenced $(P>0.05)$ by $\mathrm{LaBC}^{\circledR}$ and/or fertiliser applied to the pretreated soil when assessed in cycle 6 (Table 9). In cycle 6, when $\mathrm{LaBC}^{\circledR}$ was reapplied, there was no influence on soil MBN regardless of soil history, and there was no residual effect in cycle 7 (Table 9).

\section{Discussion}

In the absence of reapplied $\mathrm{LaBC}^{\circledR}$, there was no residual nutrient effect of a single basal application of $\mathrm{LaBC}^{\circledR}$. 
TABLE 4: Root dry biomass $\left(\mathrm{g} \mathrm{pot}^{-1}\right)$ in ryegrass cycles 6 and 7 with reapplied LaBC ${ }^{\circledR}(+/-)$ as influenced by residual effects of soil amendments from previous management history.

\begin{tabular}{|c|c|c|c|c|}
\hline \multirow{4}{*}{$\begin{array}{l}\text { Soil management history } \\
\text { (cycles } 1 \text { to } 5 \text { ) }\end{array}$} & \multicolumn{3}{|c|}{ Root dry biomass $\left(\mathrm{g} \mathrm{pot}^{-1}\right)$} & \\
\hline & \multicolumn{2}{|c|}{ Ryegrass cycle 6} & \multicolumn{2}{|c|}{ Ryegrass cycle 7} \\
\hline & \multicolumn{4}{|c|}{ Current treatment $\left(+/-\mathrm{LaBC}^{\circledR}\right)$} \\
\hline & $-\mathrm{LaBC}^{\circledR}$ & $+\mathrm{LaBC}^{\circledR}\left(50 \mathrm{tha}^{-1}\right)$ & $\begin{array}{c}\text { Treatment } \\
- \text { LaBC }^{\circledR} \text { from cycle } 6\end{array}$ & $\begin{array}{c}\text { Treatment } \\
+ \text { LaBC }^{\circledR} \text { from cycle } 6\end{array}$ \\
\hline Control & $0.23 \pm 0.03^{\mathrm{d}}$ & $0.53 \pm 0.13^{\text {cd }}$ & $0.10 \pm 0.02^{\mathrm{c}}$ & $0.50 \pm 0.10^{\mathrm{b}}$ \\
\hline${ }^{\mathrm{a}} \mathrm{LaBC}^{\circledR}$ & $0.34 \pm 0.08^{\mathrm{cd}}$ & $0.58 \pm 0.06^{\mathrm{cd}}$ & $0.31 \pm 0.09^{b c}$ & $0.45 \pm 0.06^{\mathrm{b}}$ \\
\hline${ }^{\mathrm{b}}$ Fertiliser & $1.08 \pm 0.22^{\mathrm{a}}$ & $0.57 \pm 0.15^{\mathrm{cd}}$ & $1.03 \pm 0.20^{\mathrm{a}}$ & $0.59 \pm 0.14^{\mathrm{b}}$ \\
\hline $\mathrm{LaBC}^{\circledR}+$ fertiliser & $1.03 \pm 0.12^{\mathrm{ab}}$ & $0.67 \pm 0.09^{b c}$ & $0.95 \pm 0.11^{\mathrm{a}}$ & $0.52 \pm 0.09^{b}$ \\
\hline
\end{tabular}

${ }^{\mathrm{a}} \mathrm{LaBC}^{\circledR}=50 \mathrm{tha}^{-1}$ of wet weight equivalent.

${ }^{\mathrm{b}}$ Fertiliser $=$ macronutrient fertilisers $(\mathrm{N}, \mathrm{P}, \mathrm{K}, \mathrm{Ca}$, and $\mathrm{Mg})$ applied according to district practice.

Values are mean \pm SE $(n=3)$. The letters followed by mean \pm SE were based on LSD $(P<0.05)$.

The main and interaction effects of treatments with the same letters, within the same column and between columns within each cycle, respectively, were not significant $(P>0.05)$.

TABLE 5: Root : shoot in ryegrass cycles 6 and 7 with reapplied LaBC ${ }^{\circledR}(+/-)$ as influenced by residual effects of soil amendments from previous management history.

\begin{tabular}{|c|c|c|c|c|}
\hline \multicolumn{5}{|c|}{ Root: shoot } \\
\hline \multirow{3}{*}{$\begin{array}{l}\text { Soil management history } \\
\text { (cycles } 1 \text { to 5) }\end{array}$} & \multicolumn{2}{|c|}{ Ryegrass cycle 6} & \multicolumn{2}{|c|}{ Ryegrass cycle 7} \\
\hline & \multicolumn{4}{|c|}{ Current treatment $\left(+/-\mathrm{LaBC}^{\circledR}\right)$} \\
\hline & $-\mathrm{LaBC}^{\circledR}$ & $\begin{array}{l}+\mathrm{LaBC}^{\circledR} \\
\left(50 \mathrm{tha}^{-1}\right)\end{array}$ & $\begin{array}{c}\text { Treatment } \\
- \text { LaBC }^{\circledR} \text { from cycle } 6\end{array}$ & $\begin{array}{c}\text { Treatment } \\
+ \text { LaBC }^{\circledR} \text { from cycle } 6\end{array}$ \\
\hline Control & $0.67 \pm 0.67^{\mathrm{d}}$ & $1.56 \pm 0.22^{\mathrm{bcd}}$ & $0.89 \pm 0.21^{\mathrm{b}}$ & $1.38 \pm 0.32^{\mathrm{b}}$ \\
\hline${ }^{\mathrm{a}} \mathrm{LaBC}^{\circledR}$ & $3.33 \pm 0.88^{\mathrm{ab}}$ & $1.50 \pm 0.14^{\mathrm{bcd}}$ & $3.22 \pm 0.75^{\mathrm{b}}$ & $1.48 \pm 0.13^{\mathrm{b}}$ \\
\hline${ }^{\mathrm{b}}$ Fertiliser & $4.28 \pm 1.62^{\mathrm{a}}$ & $1.45 \pm 0.37^{\mathrm{bcd}}$ & $6.64 \pm 1.13^{\mathrm{a}}$ & $1.29 \pm 0.36^{\mathrm{b}}$ \\
\hline $\mathrm{LaBC}^{\circledR}+$ fertiliser & $3.14 \pm 0.43^{\mathrm{abc}}$ & $1.13 \pm 0.16^{\mathrm{cd}}$ & $8.97 \pm 1.63^{\mathrm{a}}$ & $1.34 \pm 0.31^{\mathrm{b}}$ \\
\hline
\end{tabular}

${ }^{\mathrm{a}} \mathrm{LaBC}^{\circledR}=50 \mathrm{tha}^{-1}$ of wet weight equivalent.

${ }^{\mathrm{b}}$ Fertiliser $=$ macronutrient fertilisers $(\mathrm{N}, \mathrm{P}, \mathrm{K}, \mathrm{Ca}$, and $\mathrm{Mg})$ applied according to district practice.

Values are mean \pm SE $(n=3)$. The letters followed by mean \pm SE were based on $\operatorname{LSD}(P<0.05)$.

The main and interaction effects of treatments with the same letters, within the same column and between columns within each cycle, respectively, were not significant $(P>0.05)$, based on 2-way ANOVA.

TABLE 6: Shoot N concentration (\%) in ryegrass cycles 6 and 7 with reapplied LaBC ${ }^{\circledR}(+/-)$ as influenced by residual effects of soil amendments from previous management history.

Shoot $\mathrm{N}$ concentration (\%)

Ryegrass cycle 6

Ryegrass cycle 7

Soil management history

(cycles 1 to 5)

Current treatment $\left(+/-\mathrm{LaBC}^{\circledR}\right)$

\begin{tabular}{lcccc} 
& - LaBC $^{\circledR}$ & + LaBC $^{\circledR}\left(50 \mathrm{tha}^{-1}\right)$ & $\begin{array}{c}\text { Treatment } \\
- \text { LaBC }^{\circledR} \text { from cycle 6 }\end{array}$ & $\begin{array}{c}\text { Treatment } \\
+ \text { LaBC }\end{array}$ \\
\hline Control & $1.79 \pm 0.12^{\mathrm{cd}}$ & $2.11 \pm 0.05^{\mathrm{abc}}$ & $1.46 \pm 0.13^{\mathrm{a}}$ & $1.33 \pm 0.06^{\mathrm{a}}$ \\
${ }^{\mathrm{a}} \mathrm{LaBC}^{\circledR}$ & $1.78 \pm 0.04^{\mathrm{cd}}$ & $2.18 \pm 0.13^{\mathrm{ab}}$ & $1.58 \pm 0.06^{\mathrm{a}}$ & $1.52 \pm 0.03^{\mathrm{a}}$ \\
${ }^{\mathrm{b}}$ Fertiliser & $1.86 \pm 0.1^{\mathrm{bcd}}$ & $2.28 \pm 0.22^{\mathrm{a}}$ & $1.49 \pm 0.03^{\mathrm{a}}$ & $1.44 \pm 0.04^{\mathrm{a}}$ \\
$\mathrm{LaBC}^{\circledR}+$ fertiliser & $1.75 \pm 0.1^{\mathrm{d}}$ & $2.35 \pm 0.07^{\mathrm{a}}$ & $1.46 \pm 0.08^{\mathrm{a}}$ & $1.54 \pm 0.01^{\mathrm{a}}$ \\
\hline
\end{tabular}

${ }^{\mathrm{a}} \mathrm{LaBC}^{\circledR}=50 \mathrm{tha}^{-1}$ of wet weight equivalent.

${ }^{\mathrm{b}}$ Fertiliser $=$ macronutrient fertilisers $(\mathrm{N}, \mathrm{P}, \mathrm{K}, \mathrm{Ca}$, and $\mathrm{Mg})$ applied according to district practice.

Values are mean \pm SE $(n=3)$. The letters followed by mean \pm SE were based on $\operatorname{LSD}(P<0.05)$.

The main and interaction effects of treatments with the same letters, within the same column and between columns within each cycle, respectively, were not significant $(P>0.05)$, based on 2-way ANOVA. 
TABLE 7: Soil pH in ryegrass cycles 6 and 7 with reapplied $\mathrm{LaBC}^{\circledR}(+/-)$ as influenced by residual effects of soil amendments from previous management history.

\begin{tabular}{|c|c|c|c|c|}
\hline \multicolumn{5}{|c|}{ Soil pH } \\
\hline \multirow{3}{*}{$\begin{array}{l}\text { Soil management history } \\
\text { (cycles } 1 \text { to } 5 \text { ) }\end{array}$} & \multicolumn{2}{|c|}{ Ryegrass cycle 6} & \multicolumn{2}{|c|}{ Ryegrass cycle 7} \\
\hline & \multicolumn{4}{|c|}{ Current treatment $\left(+/-\mathrm{LaBC}^{\circledR}\right)$} \\
\hline & $-\mathrm{LaBC}^{\circledR}$ & $+\mathrm{LaBC}^{\circledR}\left(50 \mathrm{tha}^{-1}\right)$ & $\begin{array}{c}\text { Treatment } \\
- \text { LaBC }^{\circledR} \text { from cycle } 6\end{array}$ & $\begin{array}{c}\text { Treatment } \\
+\mathrm{LaBC}^{\circledR} \text { from cycle } 6\end{array}$ \\
\hline Control & $5.0 \pm 0.03^{\mathrm{d}}$ & $6.6 \pm 0.06^{\mathrm{b}}$ & $4.9 \pm 0^{\mathrm{e}}$ & $7.1 \pm 0.09^{\mathrm{b}}$ \\
\hline${ }^{\mathrm{a}} \mathrm{LaBC} \mathrm{C}^{\circledR}$ & $5.4 \pm 0.00^{c}$ & $6.8 \pm 0.06^{\mathrm{a}}$ & $5.4 \pm 0.03^{c}$ & $7.4 \pm 0.07^{\mathrm{a}}$ \\
\hline${ }^{\mathrm{b}}$ Fertiliser & $4.7 \pm 0.03^{\mathrm{e}}$ & $6.5 \pm 0.12^{\mathrm{b}}$ & $4.6 \pm 0.03^{\mathrm{f}}$ & $7.1 \pm 0.06^{\mathrm{b}}$ \\
\hline $\mathrm{LaBC}^{\circledR}+$ fertiliser & $5.3 \pm 0.07^{c}$ & $6.9 \pm 0.09^{\mathrm{a}}$ & $5.2 \pm 0.06^{\mathrm{d}}$ & $7.2 \pm 0.06^{b}$ \\
\hline
\end{tabular}

${ }^{\mathrm{a}} \mathrm{LaBC}^{\circledR}=50 \mathrm{tha}^{-1}$ of wet weight equivalent.

${ }^{\mathrm{b}}$ Fertiliser $=$ macronutrient fertilisers $(\mathrm{N}, \mathrm{P}, \mathrm{K}, \mathrm{Ca}$, and $\mathrm{Mg})$ applied according to district practice.

Values are mean \pm SE $(n=3)$. The letters followed by mean \pm SE were based on $\operatorname{LSD}(P<0.05)$.

The main and interaction effects of treatments with the same letters, within the same column and between columns within each cycle, respectively, were not significant $(P>0.05)$, based on 2-way ANOVA.

TABLE 8: Total inorganic $\mathrm{N}\left(\mu \mathrm{gg}^{-1}\right.$ soil) in ryegrass cycles 6 and 7 with reapplied $\mathrm{LaBC}^{\circledR}(+/-)$ as influenced by residual effects of soil amendments from previous management history.

\begin{tabular}{|c|c|c|c|c|}
\hline \multirow{4}{*}{$\begin{array}{l}\text { Soil management history } \\
\text { (cycles } 1 \text { to } 5 \text { ) }\end{array}$} & \multicolumn{3}{|c|}{ Total inorganic $\mathrm{N}\left(\mu \mathrm{g} \mathrm{g}^{-1}\right.$ soil $)$} & \\
\hline & \multicolumn{2}{|c|}{ Ryegrass cycle 6} & \multicolumn{2}{|c|}{ Ryegrass cycle 7} \\
\hline & \multicolumn{4}{|c|}{ Current treatment $\left(+/-\mathrm{LaBC}^{\circledR}\right)$} \\
\hline & $-\mathrm{LaBC}^{\circledR}$ & $+\mathrm{LaBC}^{\circledR}\left(50 \mathrm{tha}^{-1}\right)$ & $\begin{array}{c}\text { Treatment } \\
- \text { LaBC }^{\circledR} \text { from cycle } 6\end{array}$ & $\begin{array}{c}\text { Treatment } \\
+ \text { LaBC }^{\circledR} \text { from cycle } 6\end{array}$ \\
\hline Control & $0 \pm 0^{\mathrm{d}}$ & $0.68 \pm 0.33^{\mathrm{cd}}$ & $0.20 \pm 0.06^{\mathrm{b}}$ & $0.33 \pm 0.17^{\mathrm{ab}}$ \\
\hline${ }^{\mathrm{a}} \mathrm{LaBC}^{\circledR}$ & $0.25 \pm 0.25^{\mathrm{cd}}$ & $0.92 \pm 0.04^{\mathrm{bc}}$ & $0.20 \pm 0.15^{\mathrm{b}}$ & $0.60 \pm 0^{\mathrm{a}}$ \\
\hline${ }^{\mathrm{b}}$ Fertiliser & $0.09 \pm 0.09^{\mathrm{d}}$ & $1.70 \pm 0.37^{\mathrm{a}}$ & $0.37 \pm 0.09^{\mathrm{ab}}$ & $0.63 \pm 0.07^{\mathrm{a}}$ \\
\hline $\mathrm{LaBC}^{\circledR}+$ fertiliser & $0.29 \pm 0.14^{\mathrm{d}}$ & $1.50 \pm 0.43^{\mathrm{ab}}$ & $0.37 \pm 0.12^{\mathrm{ab}}$ & $0.43 \pm 0.15^{\mathrm{ab}}$ \\
\hline
\end{tabular}

${ }^{\mathrm{a}} \mathrm{LaBC}^{\circledR}=50 \mathrm{tha}^{-1}$ of wet weight equivalent.

${ }^{\mathrm{b}}$ Fertiliser $=$ macronutrient fertilisers $(\mathrm{N}, \mathrm{P}, \mathrm{K}, \mathrm{Ca}$, and $\mathrm{Mg})$ applied according to district practice.

Values are mean \pm SE $(n=3)$. The letters followed by mean \pm SE were based on $\operatorname{LSD}(P<0.05)$.

The main and interaction effects of treatments with the same letters, within the same column and between columns within each cycle, respectively, were not significant $(P>0.05)$, based on 2-way ANOVA.

TABLE 9: Microbial biomass N ( $\mu \mathrm{gg}^{-1}$ soil) in ryegrass cycles 6 and 7 with reapplied $\mathrm{LaBC}^{\circledR}(+/-)$ as influenced by residual effects of soil amendments from previous management history.

$$
\operatorname{MBN}\left(\mu \mathrm{gg}^{-1}\right. \text { soil) }
$$

Ryegrass cycle 6

Soil management history

Current treatment $\left(+/-\mathrm{LaBC}^{\circledR}\right)$

(cycles 1 to 5)

\begin{tabular}{lcccc} 
(cycles 1 to 5) & $-\mathrm{LaBC}^{\circledR}$ & $+\mathrm{LaBC}^{\circledR}\left(50 \mathrm{tha}^{-1}\right)$ & $\begin{array}{c}\text { Treatment } \\
- \text { LaBC }^{\circledR} \text { from cycle 6 }\end{array}$ & $\begin{array}{c}\text { Treatment } \\
+ \text { LaBC }\end{array}$ \\
\hline from cycle 6
\end{tabular}

${ }^{\mathrm{a}} \mathrm{LaBC}^{\circledR}=50 \mathrm{tha}^{-1}$ of wet weight equivalent.

${ }^{\mathrm{b}}$ Fertiliser $=$ macronutrient fertilisers $(\mathrm{N}, \mathrm{P}, \mathrm{K}, \mathrm{Ca}$, and $\mathrm{Mg})$ applied according to district practice.

Values are mean \pm SE $(n=3)$. The letters followed by mean \pm SE were based on $\operatorname{LSD}(P<0.05)$.

The main and interaction effects of treatments with the same letters, within the same column and between columns within each cycle, respectively, were not significant $(P>0.05)$, based on 2-way ANOVA. 
However, soil $\mathrm{pH}$ was maintained at a significantly higher level, indicating a residual liming effect of the previously applied $\mathrm{LaBC}^{\circledR}$ in this acid soil. Furthermore, increased ryegrass shoot and root weight were associated with a residual effect of fertiliser history in addition to the direct nutrient release from reapplied $\mathrm{LaBC}^{\circledR}$. The effect of reapplied $\mathrm{LaBC}^{\circledR}$ was generally confined to plant growth cycle. Where there were benefits of $\mathrm{LaBC}^{\circledR}$, there was no corresponding change in microbial biomass $\mathrm{N}$.

Combined application of organic amendments and inorganic mineral fertilisers is a balanced approach while budgeting plant nutrient management and carbon sequestration practices [37-41]. Inorganic soluble $\mathrm{N}$ fertilisation effects on vegetation cover, plant biomass, and yield $[42,43]$ can be immediately noticeable, significantly higher, and longlasting [39, 44-48]. For example, application of inorganic $\mathrm{N}$ $\left(37 \mathrm{~kg} \mathrm{ha}^{-1}\right)$ and $\mathrm{P}\left(94 \mathrm{~kg} \mathrm{ha}^{-1}\right)$ fertilisers increased growth of both shoot and root biomass and increased the root: shoot ratio of cool-season wheatgrass (Agropyron sp.) when grown in a low fertile strip mine soil under glasshouse and field conditions [49]. In a 3-year study [46], a single application of inorganic fertilisers $\left(100 \mathrm{~kg} \mathrm{~N}\right.$ and $\left.35 \mathrm{~kg} \mathrm{Pha}^{-1}\right)$ on a degraded semiarid ecosystem continuously supported a significantly higher native plant cover with shrubs and grasses (to 29\%) after 24 months compared with a single application of screened and unscreened biosolid and municipal waste composts (each at $40 \mathrm{tha}^{-1}$, supplied a range of nutrients $10-54 \mathrm{~kg} \mathrm{~N}$ and 6-68 $\mathrm{kg} \mathrm{Pha}{ }^{-1}$ ). The root biomass and root length did not differ significantly between treatments, but the root: shoot was significantly lower (2.1) with inorganic fertiliser application associated with increased shoot biomass. However, the effect was less pronounced after 3 years. Similarly, in the evaluation of residual effects of the biosolid product $\mathrm{LaBC}{ }^{\circledR}$ and fertiliser in our study, residual effects of $\mathrm{LaBC}^{\circledR}$ were minimal compared with the residual effects of fertiliser.

$\mathrm{LaBC}^{\circledR}$ had a residual effect on increasing soil $\mathrm{pH}$, primarily due to the incorporation of lime into this biosolids byproduct. In contrast, continuous application of mineral fertilisers, especially inorganic $\mathrm{N}$, can acidify the soil environment [50] as was demonstrated in cycles 6 and 7 of our study where there was a decrease in soil $\mathrm{pH}\left(\mathrm{CaCl}_{2}\right)$ (to 4.6) associated with inorganic fertiliser application. An increase in soil $\mathrm{pH}$ can potentially increase $\mathrm{N}$ mineralisation and organic substrate availability thereby increasing microbial biomass and its activity [51]. Similar liming effects have been shown in an incubation study over 56 days [31].

In contrast with the residual liming effect, inorganic $\mathrm{N}$ released from $\mathrm{LaBC}^{\circledR}$ was not sufficient to carry over to a sixth cycle of ryegrass growth after a single application. Soil N mineralisation is considered to be a crucial factor while determining agronomical values of organic amendments [52]. Soil inorganic $\mathrm{N}$ was significantly higher only when $\mathrm{LaBC}^{\circledR}$ was reapplied in soils that had received either mineral fertiliser alone or mineral fertiliser in combination with $\mathrm{LaBC}^{\circledR}$ application in the past. In addition to the residual effect of inorganic fertilisers, the added slow release nutrients from reapplied $\mathrm{LaBC}^{\circledR}$ contributed to plant available nutrients only within one ryegrass growth cycle 6 . This implies that $\mathrm{LaBC}^{\circledR}$ reapplied after previous basal application of $\mathrm{LaBC}^{\circledR}\left(50 \mathrm{tha}^{-1}\right.$ wet weight equivalent) would contribute little towards the potential of $\mathrm{N}$ leaching into the immediate environment.

Increased soil microbial biomass and activities indicate improved biological components of soil fertility status after application of organic amendments $[53,54]$. Nevertheless, in the acid sandy soil used in this study, reapplied $\mathrm{LaBC}^{\circledR}$ did not increase microbial biomass $\mathrm{N}$ although soil $\mathrm{pH}$ and mineralisation based on soil inorganic $\mathrm{N}$ were higher with reapplied $\mathrm{LaBC}^{\circledR}$. In contrast, microbial biomass $\mathrm{N}$ changed over time with application of $\mathrm{LaBC}^{\circledR}$ in the absence of plants [19]; the presence of plants may have introduced competition for $\mathrm{N}$ at the level of $\mathrm{LaBC}^{\circledR}$ applied $\left(50 \mathrm{tha}^{-1}\right)$.

\section{Conclusions}

(i) As hypothesised, reapplication of a lime- and clayamended biosolids product, $\mathrm{LaBC}^{\circledR}$, had an immediate effect of increasing soil $\mathrm{pH}$ regardless of prior history of $\mathrm{LaBC}^{\circledR}$ and fertiliser application. The main benefit of $\mathrm{LaBC}^{\circledR}$ was to increase soil $\mathrm{pH}\left(\mathrm{CaCl}_{2}\right)$ which was maintained at about 5.4 even after 6 cycles of ryegrass growth following a single application.

(ii) The second hypothesis is that the application of $\mathrm{LaBC}^{\circledR}$ to soil with a fertiliser history would release more $\mathrm{N}$ and increase ryegrass growth to a greater extent than an application of $\mathrm{LaBC}^{\circledR}$ to soil without a fertiliser history; this was not supported.

(iii) The release of inorganic $\mathrm{N}$ with reapplied $\mathrm{LaBC}^{\circledR}$ appeared to be confined to the current growth cycle, with little or no residual effect.

(iv) Our investigation demonstrates that both reapplied and previously applied $\mathrm{LaBC}^{\circledR}$ at $50 \mathrm{tha}^{-1}$ wet weight equivalent are unlikely to pose a risk of leachable $\mathrm{N}$ in this sandy soil, based on the available soil inorganic $\mathrm{N}$ measured.

\section{Conflict of Interests}

The authors declare that there is no conflict of interests regarding the publication of this paper.

\section{Acknowledgments}

The authors acknowledge the support of Dr. Robert Humphries and Tom Long for this research and for providing the biosolids products and access to field sites for soil collection. They thank Rebecca Ovens for support in sharing soil management history of the glasshouse experiments. Sanjutha Shanmugam was awarded a Ph.D. Scholarship, UWASIRF (The University of Western Australia-Scholarship for International Research Fee) with financial support of the Water Corporation of Western Australia. 


\section{References}

[1] D. Pritchard and D. Collins, "The National Biosolids Research Program: Research Studies on the Impact of Heavy Metals on Sustainable Fertilisation and the Intensive Agricultural Applications of Biosolids," Final Report to the Water Corporation of Western Australia Contract XX-03-11200, December 2006.

[2] N. R. Viney and M. Sivapalan, "Modelling catchment processes in the Swan-Avon river basin," Hydrological Processes, vol. 15, no. 13, pp. 2671-2685, 2001.

[3] C. Zammit, M. Sivapalan, P. Kelsey, and N. R. Viney, "Modelling the effects of land-use modifications to control nutrient loads from an agricultural catchment in Western Australia," Ecological Modelling, vol. 187, no. 1, pp. 60-70, 2005.

[4] B. J. Robson, P. A. Bukaveckas, and D. P. Hamilton, "Modelling and mass balance assessments of nutrient retention in a seasonally-flowing estuary (Swan River Estuary, Western Australia)," Estuarine, Coastal and Shelf Science, vol. 76, no. 2, pp. 282-292, 2008.

[5] R. Humphries, T. Long, K. Walton, and D. Allen, "From waste to water quality-opportunities for achieving sustainable urban development on the sandy soils of the Swan Coastal Plain, Western Australia," in Proceedings of the 6th International Water Sensitive Urban Design Conference (WSUD '09), Western Australia, Australia, 2009.

[6] R. Ovens, Report on LaBC ${ }^{\circledR}$ Field Trial to Water Corporation, Water Corporation, Perth, Australia, 2009.

[7] R. Mata-González, R. E. Sosebee, and C. Wan, "Effect of types of biosolids and cattle manure on desert grass growth," Rangeland Ecology and Management, vol. 59, no. 6, pp. 664-667, 2006.

[8] D. M. Sullivan, "Biosolids increase grass yield, grass quality and soil fertility in dryland pasture," Report, Bureau of Environmental Services Monitoring Data, City of Portland, Oregon State University, 2008.

[9] G. C. Sigua, "Recycling biosolids and lake-dredged materials to pasture-based animal agriculture: alternative nutrient sources for forage productivity and sustainability: a review," in Sustainable Agriculture Part 5, E. Lichtfouse, Ed., pp. 495-517, Springer, Dordrecht, The Netherlands, 2009.

[10] D. C. Lewis, A. L. Clarke, and W. B. Hall, "Accumulation of plant nutrients and changes in soil properties of sandy soils under fertilized pasture in South-eastern South Australia. I. Phosphorus," Australian Journal of Soil Research, vol. 25, pp. 193-202, 1987.

[11] R. N. Summers, N. R. Guise, D. D. Smirk, and K. J. Summers, "Bauxite residue (red mud) improves pasture growth on sandy soils in Western Australia," Australian Journal of Soil Research, vol. 34, no. 4, pp. 569-581, 1996.

[12] O. Stabnikova, W.-K. Goh, H.-B. Ding, J.-H. Tay, and J.-Y. Wang, "The use of sewage sludge and horticultural waste to develop artificial soil for plant cultivation in Singapore," Bioresource Technology, vol. 96, no. 9, pp. 1073-1080, 2005.

[13] W. C. Gardner, K. Broersma, A. Naeth, D. Chanasyk, and A. Jobson, "Influence of biosolids and fertilizer amendments on physical, chemical and microbiological properties of copper mine tailings," Canadian Journal of Soil Science, vol. 90, no. 4, pp. 571-583, 2010.

[14] J. J. Sloan and N. T. Basta, "Remediation of acid soils by using alkaline biosolids," Journal of Environmental Quality, vol. 24, no. 6, pp. 1097-1103, 1995.

[15] R. J. Haynes and R. Naidu, "Influence of lime, fertilizer and manure applications on soil organic matter content and soil physical conditions: a review, Nutrient Cycling in Agroecosystems, vol. 51, no. 2, pp. 123-137, 1998.

[16] A. Farhoodi and D. R. Coventry, "Field crop responses to lime in the mid-north region of South Australia," Field Crops Research, vol. 108, no. 1, pp. 45-53, 2008.

[17] Y. Luo and P. Christie, "Alleviation of soil acidity and aluminium phytotoxicity in acid soils by using alkaline-stabilised biosolids," Pedosphere, vol. 12, no. 2, pp. 185-188, 2002.

[18] D. Pritchard, H. Rigby, and D. Collins, "Research studies on the impact of the agricultural application of lime-amended biosolids," Final Report To Water Corporation, Contract CN06-12930, Western Australia, Australia, 2010.

[19] S. Shanmugam, L. K. Abbott, and D. V. Murphy, "Clay addition to lime-amended biosolids overcomes water repellence and provides nitrogen supply in an acid sandy soil," Biology and Fertility of Soils, vol. 50, no. 7, pp. 1047-1059, 2014.

[20] J. J. Kelly, E. Favila, L. S. Hundal, and J. C. Marlin, "Assessment of soil microbial communities in surface applied mixtures of Illinois River sediments and biosolids," Applied Soil Ecology, vol. 36, no. 2-3, pp. 176-183, 2007.

[21] J. K. Keller, S. D. Bridgham, C. T. Chapin, and C. M. Iversen, "Limited effects of six years of fertilization on carbon mineralization dynamics in a Minnesota fen," Soil Biology and Biochemistry, vol. 37, no. 6, pp. 1197-1204, 2005.

[22] J. B. Zhang, T. B. Zhu, Z. C. Cai, S. W. Qin, and C. Müller, "Effects of long-term repeated mineral and organic fertilizer applications on soil nitrogen transformations," European Journal of Soil Science, vol. 63, no. 1, pp. 75-85, 2012.

[23] R. Harrison, D. Xue, C. Henry, and D. W. Cole, "Long-term effects of heavy applications of biosolids on organic matter and nutrient content of a coarse-textured forest soil," Forest Ecology and Management, vol. 66, no. 1-3, pp. 165-177, 1994.

[24] T. W. Speir, A. P. van Schaik, A. R. Lloyd-Jones, and H. A. Kettles, "Temporal response of soil biochemical properties in a pastoral soil after cultivation following high application rates of undigested sewage sludge," Biology and Fertility of Soils, vol. 38, no. 6, pp. 377-385, 2003.

[25] T. S. Sullivan, M. E. Stromberger, and M. W. Paschke, "Parallel shifts in plant and soil microbial communities in response to biosolids in a semi-arid grassland," Soil Biology and Biochemistry, vol. 38, no. 3, pp. 449-459, 2006.

[26] T. S. Sullivan, M. E. Stromberger, M. W. Paschke, and J. A. Ippolito, "Long-term impacts of infrequent biosolids applications on chemical and microbial properties of a semi-arid rangeland soil," Biology and Fertility of Soils, vol. 42, no. 3, pp. 258-266, 2006.

[27] M. Kaiser, R. H. Ellerbrock, and H. H. Gerke, "Long-term effects of crop rotation and fertilization on soil organic matter composition," European Journal of Soil Science, vol. 58, no. 6, pp. 1460-1470, 2007.

[28] W.-D. Kong, Y.-G. Zhu, B.-J. Fu, X.-Z. Han, L. Zhang, and J.Z. He, "Effect of long-term application of chemical fertilizers on microbial biomass and functional diversity of a black soil," Pedosphere, vol. 18, no. 6, pp. 801-808, 2008.

[29] D. R. Coventry and J. R. Hirth, "Effects of tillage and lime on Rhizobium trifolii populations and survival in wheatsubterranean clover rotation in Southeastern Australia," Soil and Tillage Research, vol. 25, no. 1, pp. 67-74, 1992.

[30] S. J. Kemmitt, D. Wright, K. W. T. Goulding, and D. L. Jones, "pH regulation of carbon and nitrogen dynamics in two agricultural soils," Soil Biology and Biochemistry, vol. 38, no. 5, pp. 898-911, 2006. 
[31] J. P. Fuentes, D. F. Bezdicek, M. Flury, S. Albrecht, and J. L. Smith, "Microbial activity affected by lime in a long-term notill soil," Soil and Tillage Research, vol. 88, no. 1-2, pp. 123-131, 2006.

[32] G. Sellers, S. G. McRae, and H. F. Cook, "Ryegrass, fescue and clover growth on London Clay amended with waste materials," Land Contamination and Reclamation, vol. 10, no. 2, pp. 79-89, 2002.

[33] S. M. Eldridge, K. Y. Chan, Z. H. Xu, C. R. Chen, and I. Barchia, "Plant-available nitrogen supply from granulated biosolids: implications for land application guidelines," Australian Journal of Soil Research, vol. 46, no. 5, pp. 423-436, 2008.

[34] R. F. Isbell, The Australian Soil Classification, CSIRO Publishing, Melbourne, Australia, 1996.

[35] G. E. Rayment and F. R. Higginson, Australian Laboratory Handbook of Soil and Water Chemical Method, Inkata Press, Melbourne, Australia, 1992.

[36] D. W. Nelson and L. E. Sommers, "Total carbon, organic carbon and organic matter," in Methods of Soil Analysis-Part 2: Chemical and Microbiological Properties, A. L. Page, R. H. Miller, and D. R. Keeney, Eds., pp. 539-579, American Society of Agronomy, Madison, Wis, USA, 1982.

[37] Z. C. Cai and S. W. Qin, "Dynamics of crop yields and soil organic carbon in a long-term fertilization experiment in the Huang-Huai-Hai Plain of China," Geoderma, vol. 136, no. 3-4, pp. 708-715, 2006.

[38] M. Ros, S. Klammer, B. Knapp, K. Aichberger, and H. Insam, "Long-term effects of compost amendment of soil on functional and structural diversity and microbial activity," Soil Use and Management, vol. 22, no. 2, pp. 209-218, 2006.

[39] G. Pan, P. Zhou, Z. Li et al., "Combined inorganic/organic fertilization enhances $\mathrm{N}$ efficiency and increases rice productivity through organic carbon accumulation in a rice paddy from the Tai Lake region, China," Agriculture, Ecosystems and Environment, vol. 131, no. 3-4, pp. 274-280, 2009.

[40] A. Chakraborty, K. Chakrabarti, A. Chakraborty, and S. Ghosh, "Effect of long-term fertilizers and manure application on microbial biomass and microbial activity of a tropical agricultural soil," Biology and Fertility of Soils, vol. 47, pp. 303-307, 2010.

[41] S.-X. Wang, X.-Q. Liang, Q.-X. Luo et al., "Fertilization increases paddy soil organic carbon density," Journal of Zhejiang University: Science B, vol. 13, no. 4, pp. 274-282, 2012.

[42] J. C. Guevara, C. R. Stasi, O. R. Estevez, and H. N. Le Houérou, "N and $\mathrm{P}$ fertilization on rangeland production in Midwest Argentina," Journal of Range Management, vol. 53, no. 4, pp. 410-414, 2000.

[43] T. L. Springer and C. M. Taliaferro, "Crop quality \& utilization: nitrogen fertilization of buffalograss," Crop Science, vol. 41, no. 1, pp. 139-142, 2001.

[44] B. Majumder, B. Mandal, P. K. Bandyopadhyay, and J. Chaudhury, "Soil organic carbon pools and productivity relationships for a 34 year old rice-wheat-jute agroecosystem under different fertilizer treatments," Plant and Soil, vol. 297, no. 1-2, pp. 53-67, 2007.

[45] P. Nayak, D. Patel, B. Ramakrishnan, A. K. Mishra, and R. N. Samantaray, "Long-term application effects of chemical fertilizer and compost on soil carbon under intensive rice-rice cultivation," Nutrient Cycling in Agroecosystems, vol. 83, no. 3, pp. 259-269, 2009.

[46] E. Kowaljow, M. J. Mazzarino, P. Satti, and C. JiménezRodríguez, "Organic and inorganic fertilizer effects on a degraded Patagonian rangeland," Plant and Soil, vol. 332, no. 1, pp. 135-145, 2010.

[47] R. J. López-Bellido, J. M. Fontán, F. J. López-Bellido, and L. López-Bellido, "Carbon sequestration by tillage, rotation, and nitrogen fertilization in a mediterranean vertisol," Agronomy Journal, vol. 102, no. 1, pp. 310-318, 2010.

[48] Z. Luo, E. Wang, and O. J. Sun, "Soil carbon change and its responses to agricultural practices in Australian agroecosystems: a review and synthesis," Geoderma, vol. 155, no. 3-4, pp. 211-223, 2010.

[49] J. L. Holechek, "Fertilizer effects on above- and below ground biomass of four species," Journal of Range Management, vol. 35, pp. 39-42, 1982.

[50] R. K. Xu, D. R. Coventry, A. Farhoodi, and J. E. Schultz, "Soil acidification as influenced by crop rotations, stubble management, and application of nitrogenous fertiliser, Tarlee, South Australia," Australian Journal of Soil Research, vol. 40, no. 3, pp. 483-496, 2002.

[51] S. P. Neale, Z. Shah, and W. A. Adams, "Changes in microbial biomass and nitrogen turnover in acidic organic soils following liming," Soil Biology and Biochemistry, vol. 29, no. 9-10, pp. 1463-1474, 1997.

[52] T. C. Flavel and D. V. Murphy, "Carbon and nitrogen mineralization rates after application of organic amendments to soil," Journal of Environmental Quality, vol. 35, no. 1, pp. 183-193, 2006

[53] S. Melero, J. C. R. Porras, J. F. Herencia, and E. Madejon, "Chemical and biochemical properties in a silty loam soil under conventional and organic management," Soil and Tillage Research, vol. 90, no. 1-2, pp. 162-170, 2006.

[54] C. Mondini, M. L. Cayuela, T. Sinicco, M. A. SánchezMonedero, E. Bertolone, and L. Bardi, "Soil application of meat and bone meal. Short-term effects on mineralization dynamics and soil biochemical and microbiological properties," Soil Biology and Biochemistry, vol. 40, no. 2, pp. 462-474, 2008. 

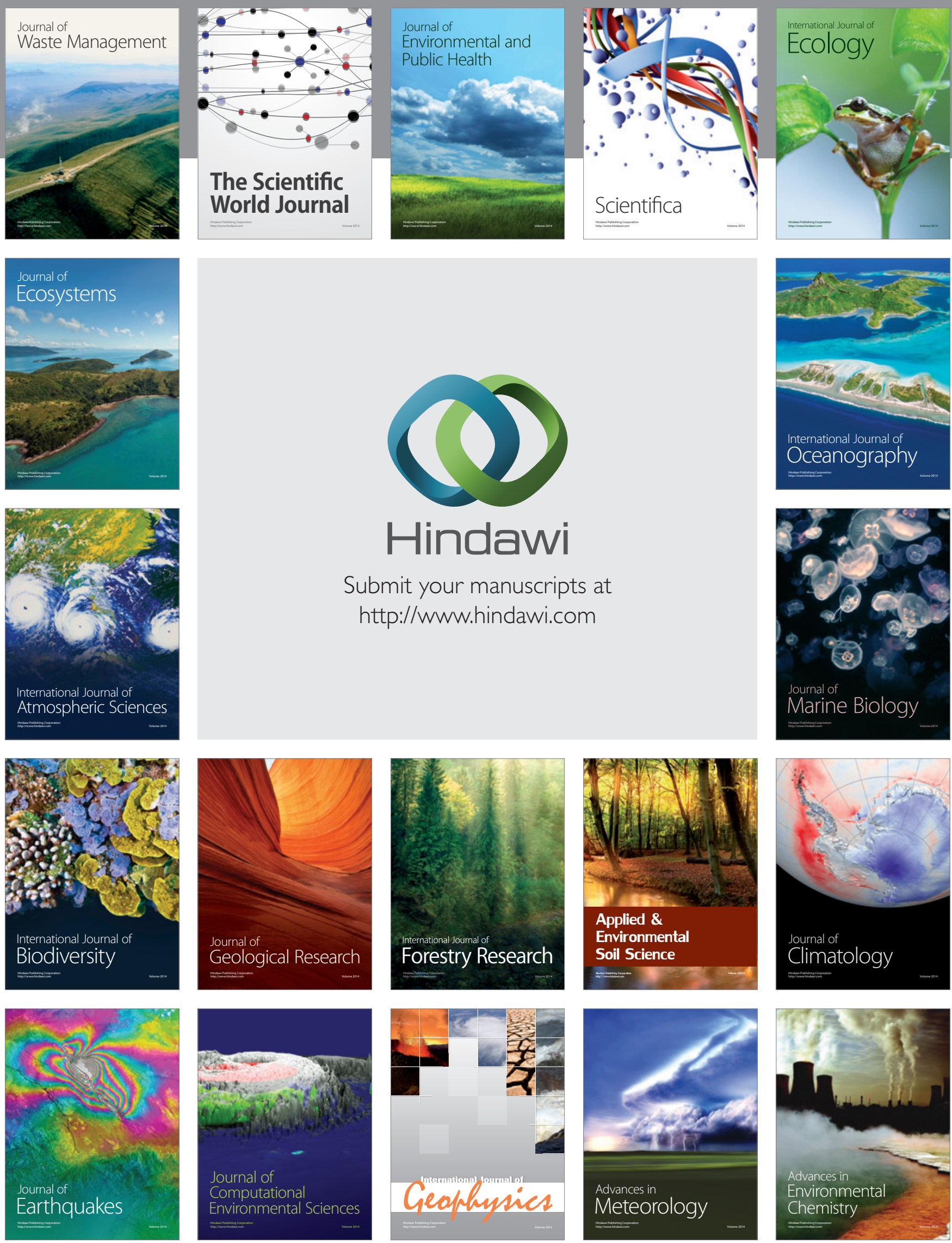